\title{
JOURNAL.RU
}

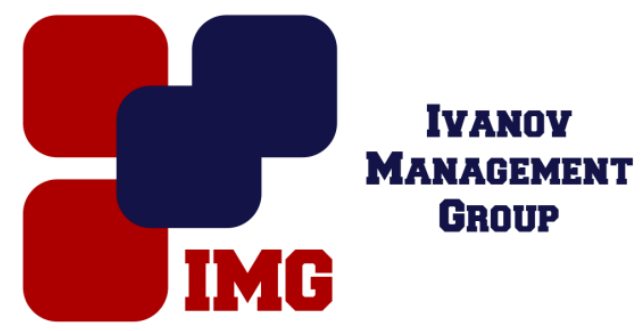

Лавёрычева С.А. ФКУ НИИФ СИН России Москва, Россия

doi: $10.18411 / 1 \mathrm{j}-30-06-2017-31$

idsp 000001:1j-30-06-2017-31

\section{К вопросу эффективности отряда хозяйственного обслуживания в следственном изоляторе}

\section{Аннотация}

В статье представлена краткая характеристика осужденных, оставленных в следственном изоляторе для выполнения работ по хозяйственному обслуживанию. Рассмотрены возможные варианты замены их другими лицами.

Ключевые слова: следственный изолятор, хозяйственное обслуживание, вольнонаемные работники.

Следственные изоляторы (СИЗО) уголовно-исполнительной системы (УИС) предназначены для содержания под стражей подозреваемых и обвиняемых в совершении преступлений. Кроме того, они выполняют функцию исполнения наказания в отношении различной категории осужденных, определенную группу среди которых занимают лица, оставленные для выполнения работ по хозяйственному обслуживанию.

Как правило, данную категорию составляют осужденные к лишению свободы, которым отбывание наказания назначено в исправительной колонии общего режима. То есть, согласно статье 58 Уголовного кодекса Российской Федерации (УК РФ), мужчинам, осужденным к лишению свободы за совершение тяжких преступлений, ранее не отбывавшим лишение свободы, а также женщинам, осужденным к лишению свободы за совершение тяжких и особо тяжких преступлений, в том числе и при любом виде рецидива. Согласно нормам уголовного и уголовно-исполнительного кодекса РФ отряд 
хозяйственного обслуживания формируется из числа осужденных-мужчин, максимальный срок наказания которых не превышает десяти лет лишения свободы и осужденных-женщин, для которых предусмотрено более строгое наказание.

Однако при формировании отряда хозяйственного обслуживания администрация СИЗО отдает предпочтение лицам, срок наказания которых не превышает пяти лет лишения свободы. Исключением являются лишь специалисты высокой квалификации.

По уголовно-исполнительному законодательству РФ осужденные из отряда хозяйственного обслуживания содержатся на условиях, предусмотренных для исправительной колонии общего режима: общие, облегченные и строгие. Однако на территории СИЗО воссоздать их в таком виде не представляется возможным, так как в них отсутствуют строгие условия отбывания наказания. Поэтому осужденных, признанных злостными нарушителями установленного порядка отбывания наказания, этапируют в исправительную колонию общего режима.

Кроме усеченного представления прогрессивной системы отбывания наказания в СИЗО, в научной литературе многие авторы отмечают еще и ужесточение режима в отношении рассматриваемой категории осужденных: постоянное нахождение их на закрытой территории, неприменение к ним положения ст. 121 УИК РФ (ч. 3), выполнение сверхурочных работ, а также низкий уровень заработной платы. Поэтому в науке все чаще отмечается необходимость рассмотрения возможности замены данного института вольнонаемными сотрудниками.

Представляется, что реализовать такое предложение на практике будет весьма проблематично. В первую очередь возникает вопрос, а возможно ли найти работников для выполнения непрестижной, малооплачиваемой работы, да еще на территории закрытого типа без предоставления дополнительных льгот? Ответ, скорее всего, будет отрицательным.

Но, если даже и удастся привлечь вольнонаемных работников для выполнения таких работ, то неизбежно возникают новые проблемы: из-за низкой заработной платы - недобросовестное выполнение своих трудовых обязанностей, а также вступление в связь с заключенными и пронос запрещенных предметов на территорию следственного изолятора. Для предотвращения этих проблем представляется необходимым увеличить заработную плату работникам и во время пребывания их на режимной 
территории обеспечить каждому сопровождение из числа сотрудников СИЗО, что требует значительных кадровых и материальных ресурсов.

Из вышесказанного сложно согласиться с высказанным мнением о целесообразности замены отряда хозяйственного обслуживания вольнонаемными работниками.

В этой связи интересна законодательная позиция в США, где в пенитенциарных учреждениях (джейлах) работы по хозяйственному обслуживанию осуществляются осужденными к кратким срокам лишения свободы.

На первый взгляд такой вариант представляется заслуживающим внимания, так как в следственных изоляторах РФ кроме осужденных, оставленных для выполнения работ, отбывают наказание еще и лица, срок лишения свободы которых не превышает шести месяцев.

Но при этом могут возникнуть сложности с комплектованием отряда хозяйственного обслуживания специалистами, знания и умения которых требуются для выполнения ряда работ (приготовление пищи, замена электрической проводки и проч.). Кроме того, в СИЗО фактически может сложиться ситуация, когда хозяйственным обслуживанием будут заниматься лица, которые ранее уже отбывали наказание в виде лишения свободы, что в свою очередь может привести к дестабилизации оперативной обстановки учреждения.

Видимо, замена осужденных в отряде хозяйственного обслуживания лицами, которым назначено наказание в виде лишения свободы на срок до шести месяцев, также как и вольнонаемными работниками, нецелесообразна.

Рассмотренные нами варианты замены отряда хозяйственного обслуживания способны привести к появлению ряда новых проблем, нежели разрешить существующие. Представляется, что на сегодняшний день, несмотря на ряд законодательных положений, которые требуют уточнения и корректировки, эффективность отряда хозяйственного обслуживания бесспорна. 
1. Уголовный кодекс Российской Федерации от 13 июня 1996 г. № 63-Ф3 // Собрание законодательства Российской Федерации - 17 июня 1996 г. - № 25 - Ст. 2954.

2. О содержании под стражей подозреваемых и обвиняемых в совершении преступлений: Федеральный закон от 15.07.1995 № 103-Ф3 [в ред. от 22.12.2014 № 446-Ф3] // Собрание законодательства РФ. - 1995. - № 29. - Ст. 2759.

3. Уголовно-исполнительный кодекс Российской Федерации: Федеральный закон от 08.01.1997 № 1-Ф3 [в ред. от 28.11.2015 № 358-Ф3] // Собрание законодательства РФ. 1997. - № 2.

4. Пенитенциарные системы зарубежных стран: учебно-практическое пособие / сост.: Гуржий В.И., Мелентьев М.П. (Общ. ред.) - Киев: РИО МВД Украины, 1993. - С. 28. 